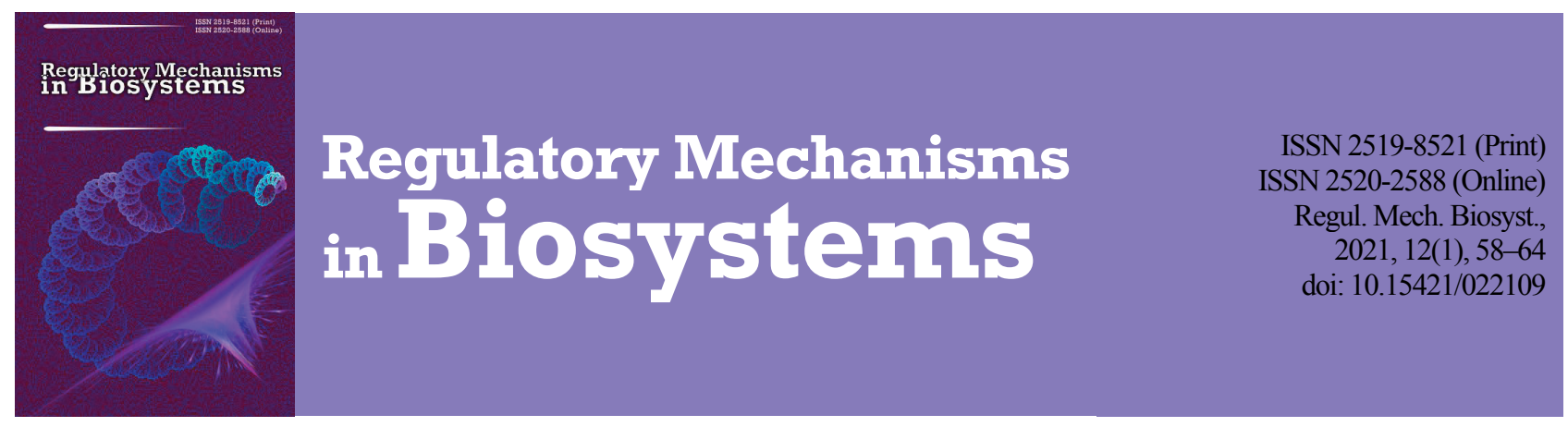

\title{
Mathematical model of transmembrane potential dynamics of loach early embryogenesis
}

\author{
G. V. Galyk, Z. Y. Fedorovych, E. I. Lychkovsky, Z. D. Vorobets \\ Danylo Halytsky Lviv National Medical University, Lviv, Ukraine
}

Article info

Received 29.01.2021

Received in revised form 25.02.2021

Accepted 27.02.2021

LvivDanylo

Halytsky National

Medical University,

Pekarska st., 69,

Lviv, 79010, Ukraine

Tel.: +38-032-275-58-76.

E-mail:

zoryana.ivanytska

@gmail.com

\section{Galyk, G. V., Fedorovych, Z. Y., Lychkovsky, E. I., \& Vorobets, Z. D. (2021). Mathematical model of transmembrane potential dynamics of loach early embryogenesis. Regulatory Mechanisms in Biosystems, 12(1), 58-64. doi:10.15421/022109}

Heavy metals in the water environment are known to have a negative effect on the viability of fish in early development. We have discussed the influence of environmental factors on early embryo development from the viewpoint of the correlation adaptometry method. The analysis of time series with the subsequent construction of a mathematical model was used to determine the change in the greatest effect of certain types of ions on the values of the transmembrane potential for prognostic purposes. The membrane potential is accepted as an integral indicator of the state of the embryos. Structures of five elements of the same type were constructed for the time shifts from 0 to 180 minutes. Each element in the system characterizes the value of the transmembrane potential that was measured in a cell incubated in one of the five solutions during early embryo development. Mathematical models describing the cell membrane potential dynamics have been created and studied. It was noted that the transmembrane potential dynamics of embryo cells is dependent on a change in the value of the correlation coefficient between elements of the system. A decrease in the sum of the correlations between individual elements of the system with an increase in the magnitude of the time shift is established. The results of the numerical solutions of the system equations indicated the sequence of changes in the greatest effect of the incubation medium on the value of the membrane potential in cells. The study of the membrane potentials' dynamics, using the total values of the strength of correlation, confirmed the influence of heavy metals in the incubation medium on the membrane potential of embryo cell in early development.

Keywords: heavy metals; nickel; cobalt; tin; zinc; biopotential; loach; embryonic development; modeling; cross-correlation.

\section{Introduction}

Reproduction and development of aquatic animals largely depends on environmental factors and are sensitive to water pollution. The research on aquatic animals has both theoretical and practical importance for making long-term ecological research in changes of development, productivity, and reproduction of organisms (Shcherbachenko, 2014; Bhagat et al., 2020). Embryonic objects in aquatic media are affected by various physical and chemical impacts, namely temperature, $\mathrm{pH}$, ionic composition of the aquatic environment, and environmental pollutants (Sfakianakis et al., 2015; Dos Santos et al., 2020). The effects on embryonic development of the environmental factors depend on their duration and strength (Isaza et al., 2020).

The heavy metals are well-known pollutants including in the aquatic environment. Heavy metals are known environmental factors. The most bioavailable form of metals that results in toxicity is mainly in the form of complexes with inorganic ligands and toxic hydrate ions in the water. The toxicity of heavy metals depends on the age of the individual, developmental stage of the embryo, as well as the dose, route of exposure, the chemical composition and, thus, the solubility of the nanoparticles, bioavailability, toxicokinetics (absorption, distribution, biotransformation, and excretion), toxicodynamics (interactions with ligands) (Kennedy, 2011; Tchounwou et al., 2012; Lacave et al., 2016). Such forms of chemicals, even at submolar concentrations, cause metabolic disorders, carcinogenic and toxic effects as well as structural changes, the development of abnormal behaviour or death (Singh et al., 2011; Seneviratne et al., 2019; Gökalp et al., 2020; Yoo et al., 2020). A wide range of negative changes in the viability of the fish embryo under influence of the heavy metals has been found (Martinez et al., 2017; Klein et al., 2019; Gouva et al., 2020). One of the effects of the heavy metals on early embryo development is the occurrence of embryonic deformities following fertilization (Kerekes et al., 2020). It was observed that combined exposures to heavy metals have a greater effect on zebrafish embryos (Aldavood et al., 2020). However, some elements, such as zinc or copper are involved in a large number of biological processes, they regulate metabolic processes and are important components of enzymes (Jakimska et al., 2011; Sonnack et al., 2017; Puar et al., 2020).

Bioelectric signaling, called the transmembrane potential plays a central role in several biological functions (Whited \& Levin, 2019). It affects many of the intercellular and intracellular functions that regulate proliferation, cell differentiation, and migration of cell, cell volume, apoptosis (Sundelacruz et al., 2009; Abdul Kadir et al., 2018).

Transmembrane potential alterations during embryogenesis represent the embryo cell state. Transmembrane potential plays a key role in embryonic development and also influences stem cells and tumour formation (Pai et al., 2016; Abdul Kadir et al., 2018; Levin \& Martyniuk, 2018). Changes in membrane potential across the plasma membrane affects cell growth (Zhou et al., 2015). The transmembrane potential, is one of the indicators of cell viability, which is sensitive to the environmental factors that affect the cell (Sfakianakis et al., 2015; Cervera et al., 2018; Cervera et al., 2019).

There are only a few literature reviews of effects of heavy metals on the transmembane potential of fish in early embryogenesis. Reviews have focused on the key questions about heavy metal accumulation in organisms, transport and toxicity in aquatic systems, metal metabolism (Sfiru et al., 2018; Wang \& Tan, 2019).

There have been many mathematical models that are applied to provide awareness of the toxicity of heavy metals or their mixture on organisms (Gerasimenko et al., 2016; Grech et al., 2017). Almost all mathematical models that describe heavy metals' metabolism belong to determi- 
nist differential equation models (Curis et al., 2009). The transmembrane potential at the early stages of embryonic development of the fresh water fish loach Misgurnus fossilis L. is used for prognostic purposes to study the effect of heavy metals on cells (Chrishtop et al., 2014). Results of time series analysis from the previous study are used for developing a mathematical model for comparing transmembrane potentials to influence of each metal on the embryo cells. The time series model indicated results that transmembrane potential for embryo cells incubated in different solutions close in time were more closely related than distant ones (Ivashkiv et al., 2001).

In this study, we developed and investigated the mathematical model of the dynamic of transmembrane potential for loach embryos incubated on the incubated media containing known concentrations of nickel (Ni), cobalt $(\mathrm{Co})$, tin $(\mathrm{Sn})$, and zinc $(\mathrm{Zn})$. The mathematical model shows similarities in the dynamics of the transmembrane potential at the influence of heavy metals on the embryo cells. This study will provide useful insight for a better understanding of the effects of heavy metals on the transmembrane potential of aquatic animals.

\section{Materials and methods}

The interest in study of the combined effect of toxic elements has arisen because of their inconsistent impacts on the environment (Yoo et al., 2020). The dynamics of the transmembrane potentials were registered for the fresh water fish loach Misgurnus fossilis L. embryos incubated on five media. Five media were used: control solution was Goldfreter's solution, $\mathrm{Ni}-$ embryos incubated in solution containing $\mathrm{Ni}^{2+}$ in concentration $10^{-5} \mathrm{M}, \mathrm{Co}-$ embryos incubated in solution containing $\mathrm{Co}^{2+}$ in concentration $10^{-4} \mathrm{M}, \mathrm{Sn}$ - embryos incubated in solution containing $\mathrm{Sn}^{2+}-10^{-4} \mathrm{M}$, $\mathrm{Zn}-$ embryos incubated in solution containing $\mathrm{Zn}^{2+}-10^{-5} \mathrm{M}$ (Boiko \& Sanagursky, 2000).

The cross-correlation coefficients were used to define the similarity between the two transmembrane potentials of embryo cells incubated in the Golfreter's solution and solutions with the heavy metals were employed to compute direction, strength, and temporal features of the metals' influence. This technique has revealed the occurrence of positive correlation and negative correlation between the pairs of transmembrane potentials of cells incubated in different solutions. The algorithm proposed in the paper (Ivashkiv et al., 2001) is used for this purpose, where the degree of similarity in transmembrane potentials is performed by cross-correlation analysis. The strengths of the relationships between ten pairs of the transmembrane potentials of embryo cells in early embryogenesis were determined.

Dynamic parameters, such as the transmembrane potential, adequately reflect the live object state in different conditions. Modeling dynamics in transmembrane potential for germ cells, incubated in media containing the highly toxic heavy metals, consists of the following steps: at the first step the coefficients of cross-correlations are determined $\mathrm{Rx}_{\mathrm{i}} \mathrm{y}_{\mathrm{j}}(\tau)$ between the values of the potential signals $(n=5)$, registered in the control and exposure to ions $\mathrm{Ni}^{2+}, \mathrm{Co}^{2+}, \mathrm{Sn}^{2+}$ and $\mathrm{Zn}^{2+}$ for specified time offsets $\tau$; on the second step the structures of mutual influence of $n$ parameters during the synchronous germ cells divisions to $360 \mathrm{~min}$ are constructed, on the third step - dynamics of potential at influence on it of ions of heavy metals is defined.

The graph analysis is used to visually represent the strength of the relationship between two signals. It is a statistical tool that detects homogeneous groups combined with the internal commonality of the studied parameters (Krishtop, 2005). The general view of a graph was mapped as an undirected graph $\mathrm{G}=(\mathrm{V}, \mathrm{E})$ where $\mathrm{V}=\left\{\mathrm{c}, \mathrm{v}_{2}, \mathrm{v}_{3}, \mathrm{v}_{4}, \mathrm{v}_{5}\right\}$ denotes the set of vertices and $\mathrm{E}$ is the set of connections between these vertices or the set of edges, that are represented as pairs of endpoints. The connection between each pair of vertices referred to the existence of a relationship between the vertices. To map a graph number of all possible connections between these vertices were defined. It is assumed that the order of placement of the elements in the scheme is not taken into account. All combinations of interaction between $\mathrm{n}$ values of transmembrane potential on the studied time interval are considered in pairs, where $n=1-5$ is the number of independent tests. The number of maximum connections for the proposed schemes is equal 10 . The obtained combinations are represented as the number of combinations of $\mathrm{n}$ elements in $\mathrm{m}$, where $1 \leq \mathrm{m} \geq \mathrm{n}$ and calculated by the formula for combinations (Anderson, 2003):

$$
C_{n}^{m}=\frac{n !}{m !(n-m)} \text {. }
$$

Graphs represent data as relationships between vertices that are the values of the signals (Fig. 1): $v_{1}$ or TMP is the transmembrane potential measured in an embryo cell incubated in Golfreter's solution, $v_{2}$ or TMP $\left(\mathrm{Ni}^{2+}\right)$ is transmembrane potential measured in an embryo cell incubated in medium with $\mathrm{Ni}^{2+}$ ions, $\mathrm{v}_{3}$ or $\operatorname{TMP}\left(\mathrm{Co}^{2+}\right)$ is transmembrane potential measured in an embryo cell incubated in medium with $\mathrm{Co}^{2+}$ ions, $\mathrm{v} 4$ or TMP $\left(\mathrm{Sn}^{2+}\right)$ is transmembrane potential measured in an embryo cell incubated in medium with $\mathrm{Sn}^{2+}$ ions, $\mathrm{v}_{5}$ or TMP $\left(\mathrm{Zn}^{2+}\right)$ is transmembrane potential measured in an embryo cell incubated in medium with $\mathrm{Zn}^{2+}$ ions.

Each vertice contains 4 connections that is a set of directed edges. Thus, the four vertices affect the fifth vertice. The edges between the vertices represent the strength of the connection and are numerically equal to the cross-correlation coefficients between the pair of the transmembrane potentials measured for cells incubated in different solutions for a given time shift of $\tau$.

In this work, a mathematical model for determining the impact of heavy metals on the transmembrane potential was developed. The developed mathematical model consists of first order ordinary differential equations with coefficients that are the sum edge weight for each node. Coefficients for model differential equations are called the sum of the correlations, because, all influences are directed towards a separate "main" element, ie there is one direction of influence to the "main" element of the system from the other four elements. The coefficient is defined as a the rate constant of interaction between two elements in the system (Razzhevaikin \& Shpitonkov, 2008).

The criterion of the intensity of population adaptation to external influences is calculated by estimation of the connectivity of the various analysis parameters using the weight of the correlation graph (Razzhevaikin \& Shpitonkov, 2008). Thus, the sum of the correlation coefficients is equal to the algebraic sum of the cross-correlation coefficients, which operate in pairs on a particular element. The values of the coefficients for the system of differential equations are found by adding the crosscorrelation coefficients. As a result, we observe that their numerical values go beyond scope $[-1 ; 1]$. For example,

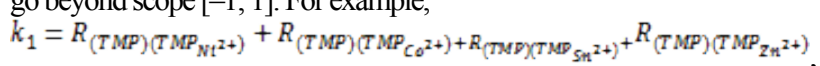
where $R_{(T M P)\left(T M P_{y}\right.}$ is the cross-correlation coefficient between the transmembrane potential of the embryo cell incubated in Golfreter's solution and the transmembrane potential of the embryo cell incubated in a solution containing Ni2+, $\quad R_{(T M P)\left(T M P_{C}\right.}$ is the cross-correlation coefficient between the transmembrane potential of the embryo cell incubated in Golfreter's solution and the transmembrane potential of the embryo cell incubated in a solution containing $\mathrm{Co}^{2+}, \quad R_{(T M P)\left(T M P_{\mathrm{s}}\right.}$ is the crosscorrelation coefficient between the transmembrane potential of the embryo cell incubated in Golfreter's solution and the transmembrane potential of the embryo cell incubated in a solution containing $\mathrm{Sn}^{2+}$,

$R_{(T M P)\left(T M P_{z}\right.}$ is the cross-correlation coefficient between the transmembrane potential of the embryo cell incubated in Golfreter's solution and the transmembrane potential of the embryo cell incubated in a solution containing $\mathrm{Zn}^{2+}$. Therefore, the coefficients are given as equal to the sum of the cross-correlation coefficients $\mathrm{k}_{\mathrm{m}}=\Sigma \mathrm{Rx}_{\mathrm{i}} \mathrm{y}_{\mathrm{j}}, \mathrm{m}=1-25$, which affect each of the five elements. The coefficients used in the mathematical model for each case of the time shift are unitless when no units are shown (Table 1).

The mathematical model of the dynamics of the transmembrane potentials in early stage of development of fish embryo with constant coefficients is:

$$
\begin{aligned}
& \frac{d y_{1}}{d t}=k_{1} y_{1}+k_{2} y_{2}+k_{3} y_{3}+k_{4} y_{4}+k_{5} y_{5} \\
& \frac{d y_{2}}{d t}=k_{6} y_{1}+k_{7} y_{2}+k_{8} y_{3}+k_{9} y_{4}+k_{10} y_{5} \\
& \frac{d y_{3}}{d t}=k_{11} y_{1}+k_{12} y_{2}+k_{13} y_{3}+k_{14} y_{4}+k_{15} y_{5}
\end{aligned}
$$


$\frac{d y_{4}}{d t}=k_{16} y_{1}+k_{17} y_{2}+k_{18} y_{3}+k_{19} y_{4}+k_{20} y_{5}$

$\frac{d y_{5}}{d t}=k_{21} y_{1}+k_{22} y_{2}+k_{23} y_{3}+k_{24} y_{4}+k_{25} y_{5}$

where $\frac{d y_{2}}{d t}$ is the rate of the transmembrane potential of an embryo cell incubated in Golfreter's solution; $\frac{a y_{z}}{d t}$ is the rate of the transmembrane potential of an embryo cell incubated in Golfreter's solution with $\mathrm{Ni}^{2+}$ ions; $\frac{d y_{1}}{d t}$ is the rate of the transmembrane potential of an embryo cell incubated in Golfreter's solution with $\mathrm{Co}^{2+}$ ions; $\frac{d y_{4}}{d t}$ is the rate of the transmembrane potential of an embryo cell incubated in Golfreter's solution with $\mathrm{Sn}^{2+}$ ions; $\frac{d y_{\bar{s}}}{d t}$ is the rate of the transmembrane potential of an embryo cell incubated in Golfreter's solution with $\mathrm{Zn}^{2+}$ ions.

Table 1

Value of parameters of the mathematical model

for each case of the time shift

\begin{tabular}{|c|c|c|c|c|c|c|c|}
\hline \multirow{3}{*}{$\begin{array}{l}\text { Coeffi- } \\
\text { cients }\end{array}$} & \multicolumn{7}{|c|}{ Time shifts } \\
\hline & $\tau=$ & $\tau=$ & $\bar{\tau}=$ & $\tau=$ & $\tau=$ & $\tau=$ & $\tau=$ \\
\hline & $0 \mathrm{~min}$ & $30 \mathrm{~min}$ & $60 \mathrm{~min}$ & $90 \mathrm{~min}$ & $120 \mathrm{~min}$ & $150 \mathrm{~min}$ & $180 \mathrm{~min}$ \\
\hline $\mathrm{k}_{1}$ & 1.55 & 2.37 & 1.98 & 1.15 & -0.38 & -1.63 & -1.42 \\
\hline $\mathrm{k}_{2}$ & 0.20 & 0.62 & 0.61 & 0.46 & 0.05 & -0.40 & -0.46 \\
\hline $\mathrm{k}_{3}$ & 0.54 & 0.67 & 0.52 & 0.27 & -0.14 & -0.43 & -0.40 \\
\hline $\mathrm{k}_{4}$ & 0.73 & 0.68 & 0.48 & 0.06 & -0.37 & -0.42 & -0.22 \\
\hline $\mathrm{k}_{5}$ & 0.08 & 0.42 & 0.36 & 0.36 & 0.09 & -0.38 & -0.37 \\
\hline $\mathrm{k}_{6}$ & 0.20 & 0.62 & 0.61 & 0.46 & 0.05 & -0.40 & -0.46 \\
\hline $\mathrm{k}_{7}$ & 2.39 & 1.26 & 0.35 & -0.11 & -0.67 & -1.10 & -0.89 \\
\hline $\mathrm{k}_{8}$ & 0.88 & 0.29 & -0.11 & -0.22 & -0.28 & -0.26 & -0.18 \\
\hline $\mathrm{k}_{9}$ & 0.66 & 0.70 & -0.15 & -0.26 & -0.30 & -0.22 & -0.10 \\
\hline $\mathrm{k}_{10}$ & 0.65 & 0.26 & -0.01 & -0.10 & -0.14 & -0.21 & -0.15 \\
\hline $\mathrm{k}_{11}$ & 0.56 & 0.67 & 0.52 & 0.27 & -0.14 & -0.43 & -0.40 \\
\hline $\mathrm{k}_{12}$ & 0.88 & 0.29 & -0.11 & -0.22 & -0.28 & -0.26 & -0.18 \\
\hline $\mathrm{k}_{13}$ & 2.89 & 1.74 & 0.61 & 0.07 & -0.94 & -1.39 & -0.98 \\
\hline $\mathrm{k}_{14}$ & 0.87 & 0.38 & 0.06 & -0.19 & -0.42 & -0.36 & -0.16 \\
\hline $\mathrm{k}_{15}$ & 0.60 & 0.40 & 0.14 & 0.08 & -0.10 & -0.34 & -0.24 \\
\hline $\mathrm{k}_{16}$ & 0.73 & 0.68 & 0.48 & 0.06 & -0.37 & -0.42 & -0.22 \\
\hline $\mathrm{k}_{17}$ & 0.63 & 0.10 & -0.15 & -0.26 & -0.30 & -0.22 & -0.10 \\
\hline $\mathrm{k}_{18}$ & 0.87 & 0.40 & 0.06 & -0.19 & -0.42 & -0.36 & -0.16 \\
\hline $\mathrm{k}_{19}$ & 2.61 & 1.82 & 0.68 & -0.35 & -1.19 & -1.36 & -0.75 \\
\hline $\mathrm{k}_{20}$ & 0.38 & 0.66 & 0.29 & 0.05 & 0.10 & -0.36 & -0.28 \\
\hline $\mathrm{k}_{21}$ & 0.08 & 0.42 & 0.36 & 0.36 & 0.09 & -0.38 & -0.34 \\
\hline $\mathrm{k}_{22}$ & 0.67 & 0.26 & -0.01 & -0.10 & -0.14 & -0.21 & -0.15 \\
\hline $\mathrm{k}_{23}$ & 0.60 & 0.40 & 0.14 & 0.08 & -0.10 & -0.34 & -0.24 \\
\hline $\mathrm{k}_{24}$ & 0.38 & 0.70 & 0.30 & 0.05 & -0.10 & -0.36 & -0.28 \\
\hline $\mathrm{k}_{25}$ & 1.73 & 1.74 & 0.80 & 0.39 & -0.24 & -1.28 & -1.01 \\
\hline
\end{tabular}

All of these parameters relate to a single system, the transmembrane potential of the loach blastomere, and reflect the state of its corresponding elements over time, so this can be used to construct a functional diagram describing their interaction.

Initial conditions for the system of differential equations are given: $\mathrm{y}_{1}(0)=-50 \mathrm{mV} ; \mathrm{y}_{2}(0)=-43.8 \mathrm{mV} ; \mathrm{y}_{3}(0)=-44.8 \mathrm{mV} ; \mathrm{y}_{4}(0)=-45.3 \mathrm{mV}$; $\mathrm{y}_{5}(0)=-45 \mathrm{mV}$ (Boiko \& Sanagursky, 2000).

The dynamic behaviour of the transmembrane potential was determined by solving the system linear ordinary differential equations numerically. The solutions of the initial value problem problem were obtained using a fourth-order Runge-Kutta method using Matlab R2014a (Yakimenko, 2019).

\section{Results}

The graphs of mutual influence of the transmembrane potential of cells of early embryos of Misgurnus fossilis L. at different cleavage stages, incubated in Golfreter's solution and media with heavy metals as $\mathrm{Ni}^{2+}$, $\mathrm{Co}^{2+}, \mathrm{Sn}^{2+}, \mathrm{Zn}^{2+}$ for the time shifts of $\tau$ from 0 to $180 \mathrm{~min}$ in a given time interval of $30 \mathrm{~min}$ are shown in Figure 1. The lines in the graph determine whether each pair of transmembrane potentials are connected, and the values of the cross-correlation coefficient are shown in Figure 1 as the scope. According to the structures (Fig. 1), the gradual change of effect caused by different incubation solutions with heavy metals or Golfreter's solution, and the control solution on the transmembrane potential was followed.

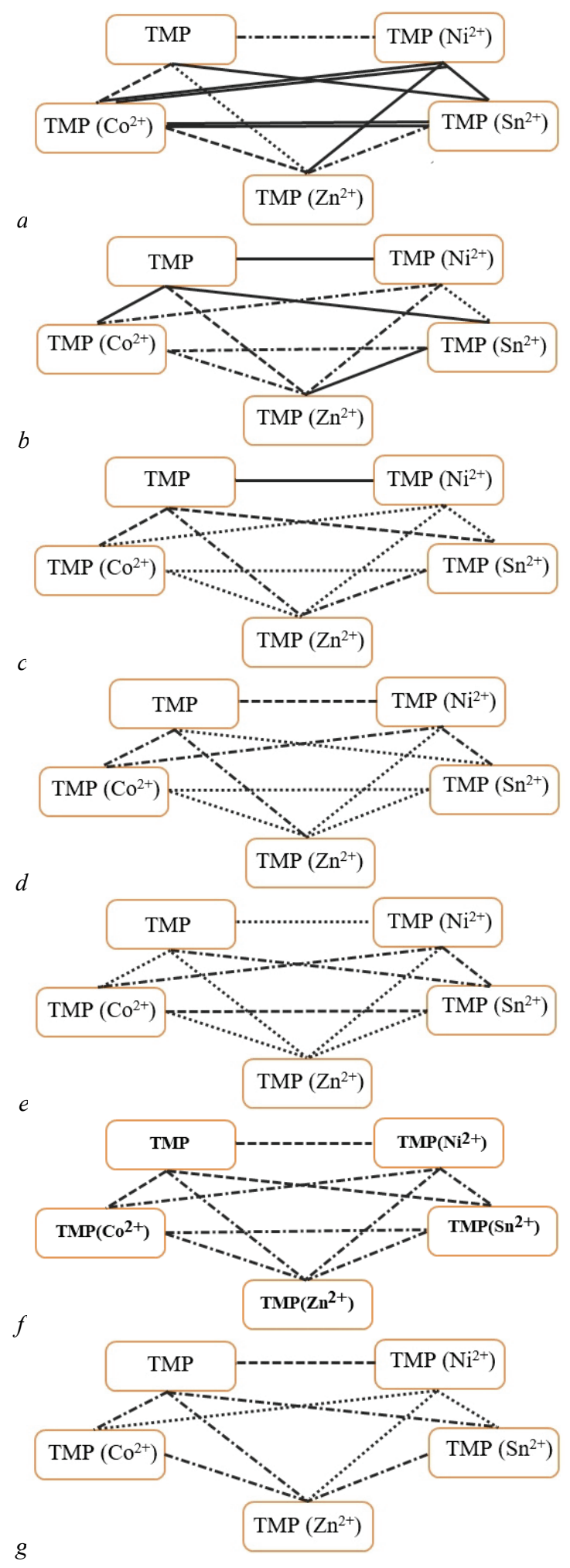

Fig. 1. The graph data structure for a five vertices at time shifts: $\tau=0 \min (a)$; at $\tau=30 \mathrm{~min}(b)$; at $\tau=60 \mathrm{~min}(c)$; at $\tau=90 \mathrm{~min}(d)$; at $\tau=120 \mathrm{~min}(e)$; at $\tau=150 \mathrm{~min}(f)$; at $\tau=180 \mathrm{~min}(\mathrm{~g}) ; \mathrm{P}=0.05 ;{ }^{*}$ - correlation magnitude:

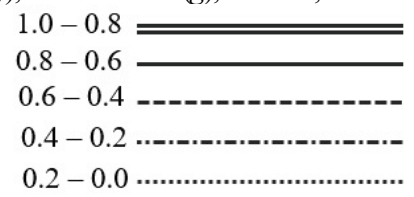

It is shown that the cross-correlation between the transmembrane potential of cells incubated in solutions containing heavy metals as $\mathrm{Ni}^{2+}$, $\mathrm{Co}^{2+}, \mathrm{Sn}^{2+}$ is very strong with zero offsets (Fig. 1a). The cross-correlation 
between pairs of transmembrane potentials of cells incubated in solution containing $\mathrm{Ni}^{2+}, \mathrm{Co}^{2+}, \mathrm{Sn}^{2+}, \mathrm{Zn}^{2+}$ ions is strong with the time shift of $\tau=$ $30 \mathrm{~min}$, indicating that the one "leader" from the heavy metals cannot be determined (Fig. 1b).

A tight relation was found between the transmembrane potential of a cell incubated in Golfreter's solution and the transmembrane potential of a cell incubated in a solution containing $\mathrm{Ni}^{2+}$ at time shifts $\tau=60$ and $90 \mathrm{~min}$ (Fig. 1c, d), but the relation was weaker than for zero offsets and tie shift of 30 min. Solutions with $\mathrm{Co}^{2+}$ and $\mathrm{Sn}^{2+}$ ions influence embryo cells at early embryo development, which results in the strong correlation between the transmembrane potentials at the time $\operatorname{shift} \tau=120 \mathrm{~min}$ (Fig. 1e).

The correlation is significant between transmembrane potentials recorded for embryo cells incubated in solutions with $\mathrm{Ni}^{2+}, \mathrm{Co}^{2+}, \mathrm{Sn}^{2+}$ ions at time shift of $\tau=150 \mathrm{~min}$ (Fig. 1f) and for the time shift of $\tau=180 \mathrm{~min}$ significant correlation is found between transmembrane potentials measured for embryos incubated with $\mathrm{Ni}^{2+}$ ions and Golfreter's solution (Fig. 1g).

The mathematical model $(I)$ was solved to establish the dynamic of the transmembrane potential behaviour over time, which depends on the magnitude of the closeness of the relationship between the elements for the experimental time shifts (Fig. 2-8).

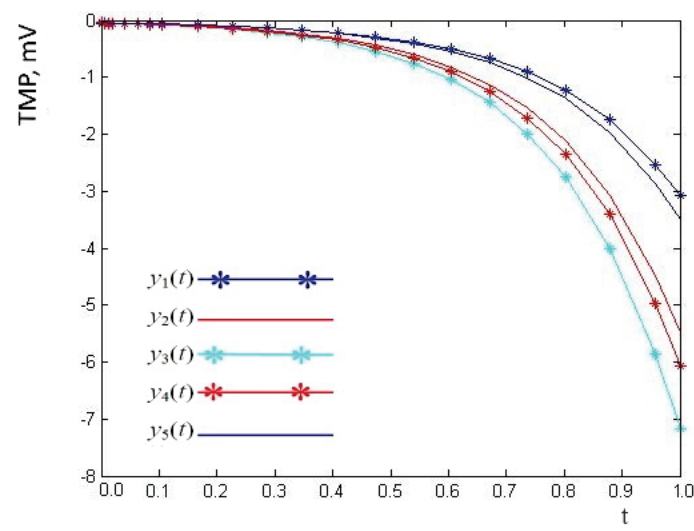

Fig. 2. The dynamics of transmembrane potential at time shift $\tau=0$ min: (1) the rate of change of the transmembrane potential of an embryo cell incubated in Golfreter's solution, (2) the rate of change of the transmembrane potential of an embryo cell incubated in a medium with $\mathrm{Ni}^{2+}$ ions, (3) the rate of change of the transmembrane potential of an embryo cell incubated in a medium with $\mathrm{Co}^{2+}$ ions, (4) the rate of change of the transmembrane potential of an embryo cell incubated in a medium with $\mathrm{Sn}^{2+}$ ions, (5) the rate of change of the transmembrane potential of an embryo cell incubated in a medium with $\mathrm{Zn}^{2+}$ ions

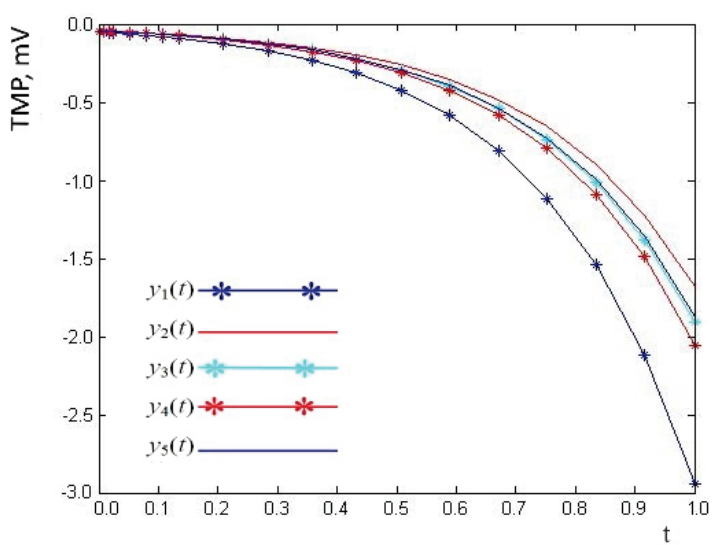

Fig. 3. The dynamics of transmembrane potential at time shift $\tau=30 \mathrm{~min}$ : (I) the rate of change of the transmembrane potential of an embryo cell incubated in Golfreter's solution, (2) the rate of change of the transmembrane potential of an embryo cell incubated in a medium with $\mathrm{Ni}^{2+}$ ions, (3) the rate of change of the transmembrane potential of an embryo cell incubated in a medium with $\mathrm{Co}^{2+}$ ions, (4) the rate of change of the transmembrane potential of an embryo cell incubated in a medium with $\mathrm{Sn}^{2+}$ ions, (5) the rate of change of the transmembrane potential of an embryo cell incubated in a medium with $\mathrm{Zn}^{2+}$ ions
The first examined was the dynamic of the of transmembrane potential under the action of heavy metals on an embryonic object in early embryogenesis at time shift $\tau$ that equals to $0 \mathrm{~min}$ (Fig. 2), time shift $\tau$ that equals to $30 \mathrm{~min}$ (Fig. 3), time shift $\tau$ that equals to $60 \mathrm{~min}$ (Fig. 4), time shift $\tau$ that equals to $90 \mathrm{~min}$ (Fig. 5), time shift $\tau$ that equals to $120 \mathrm{~min}$ (Fig. 6), time shift $\tau$ that equals to $150 \mathrm{~min}$ (Fig. 7), time shift $\tau$ that equals to $180 \mathrm{~min}$ (Fig. 8).

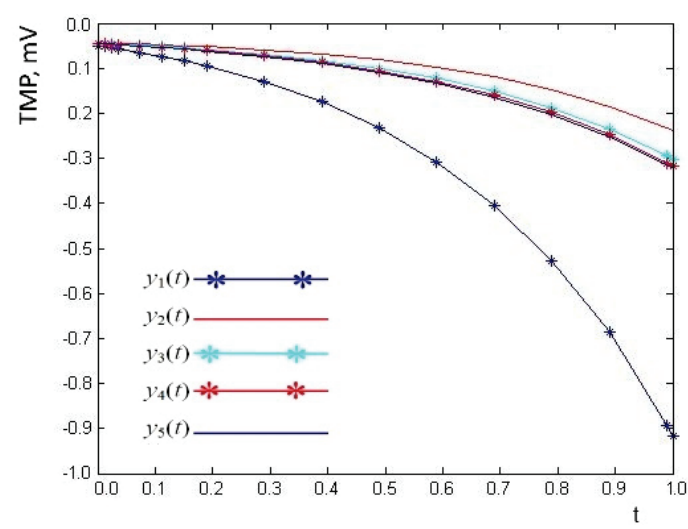

Fig. 4. The dynamics of transmembrane potential at time shift $\tau=60 \mathrm{~min}$ : (1) the rate of change of the transmembrane potential of an embryo cell incubated in Golfreter's solution, (2) the rate of change of the transmembrane potential of an embryo cell incubated in a medium with $\mathrm{Ni}^{2+}$ ions, (3) the rate of change of the transmembrane potential of an embryo cell incubated in a medium with $\mathrm{Co}^{2+}$ ions, (4) the rate of change of the transmembrane potential of an embryo cell incubated in a medium with $\mathrm{Sn}^{2+}$ ions, (5) the rate of change of the transmembrane potential of an embryo cell incubated in a medium with $\mathrm{Zn}^{2+}$ ions

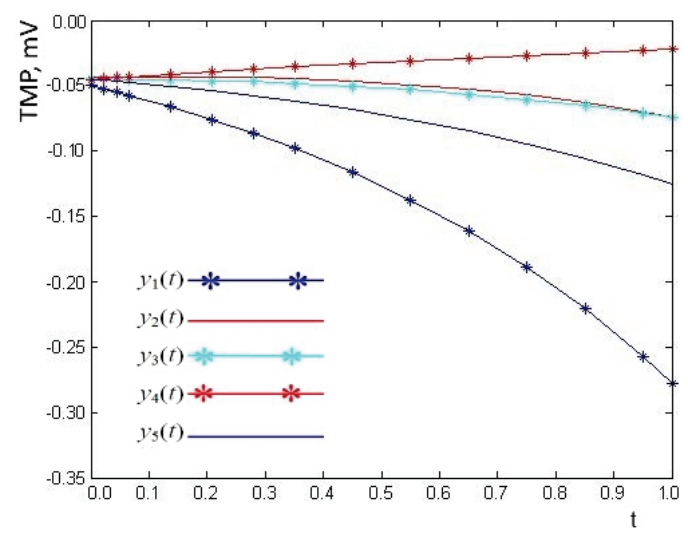

Fig. 5. The dynamics of transmembrane potential at time shift $\tau=90 \mathrm{~min}$ : (1) the rate of change of the transmembrane potential of an embryo cell incubated in Golfreter's solution, (2) the rate of change of the transmembrane potential of an embryo cell incubated in a medium with $\mathrm{Ni}^{2+}$ ions, (3) the rate of change of the transmembrane potential of an embryo cell incubated in a medium with $\mathrm{Co}^{2+}$ ions, (4) the rate of change of the transmembrane potential of an embryo cell incubated in a medium with $\mathrm{Sn}^{2+}$ ions, (5) the rate of change of the transmembrane potential of an embryo cell incubated in a medium with $\mathrm{Zn}^{2+}$ ions

The smooth changes of the non-oscillating curve predicted by our model are presented in (Fig. 2-8). The parameter values for the model equations are those listed in Table 1 . The time limit value is taken when calculating time from 0 to 1 . Figure 2 shows the similar changes in the transmembrane potential of cells over time. Numerical values of the coefficients of the equations correspond to the time shift $\tau=0 \mathrm{~min}$. The very similar results of the dynamic behaviour for the transmembrane potential were obtained that are convex monotonically decreasing functions at time shifts $\tau=0,30$ and 60 min (Fig. 2-4). Curves of the functions grown monotonically at time shift of $\tau=90-180 \mathrm{~min}$ (Fig. 5-8). Since the coefficients of the equations are positive on time shifts up to $\tau=90 \mathrm{~min}$ and the values of the coefficients are negative with $\tau=90 \mathrm{~min}$, the functions grow monotonically and are convex upwards. 


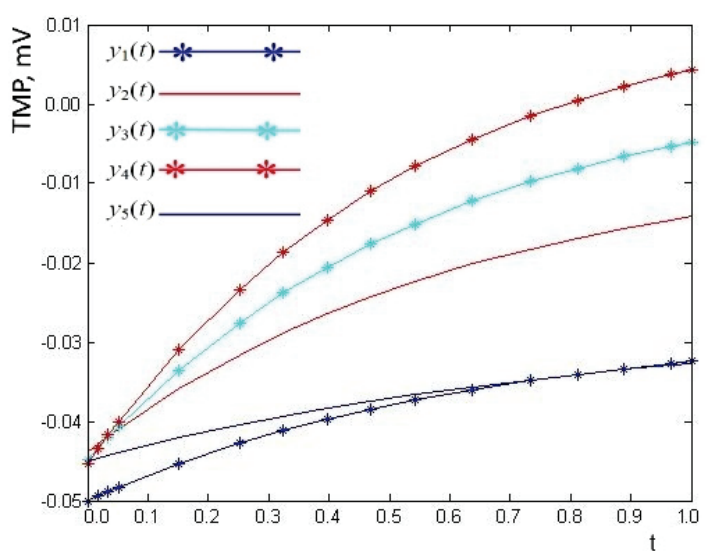

Fig. 6. The dynamics of transmembrane potential at time shift $\tau=$ $120 \mathrm{~min}$ : (I) the rate of change of the transmembrane potential of an embryo cell incubated in Golfreter's solution, (2) the rate of change of the transmembrane potential of an embryo cell incubated in a medium with $\mathrm{Ni}^{2+}$ ions, (3) the rate of change of the transmembrane potential of an embryo cell incubated in a medium with $\mathrm{Co}^{2+}$ ions, (4) the rate of change of the transmembrane potential of an embryo cell incubated in a medium with $\mathrm{Sn}^{2+}$ ions, (5) the rate of change of the transmembrane potential of an embryo cell incubated in a medium with $\mathrm{Zn}^{2+}$ ions

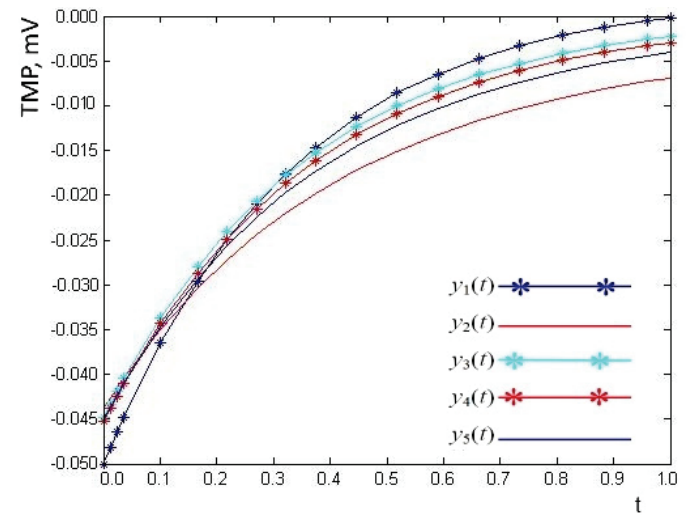

Fig. 7. The dynamics of transmembrane potential at time shift $\tau=$ $150 \mathrm{~min}$ : (1) the rate of change of the transmembrane potential of an embryo cell incubated in Golfreter's solution, (2) the rate of change of the transmembrane potential of an embryo cell incubated in a medium with $\mathrm{Ni}^{2+}$ ions, (3) the rate of change of the transmembrane potential of an embryo cell incubated in a medium with $\mathrm{Co}^{2+}$ ions, (4) the rate of change of the transmembrane potential of an embryo cell incubated in a medium with $\mathrm{Sn}^{2+}$ ions, (5) the rate of change of the transmembrane potential of an embryo cell incubated in a medium with $\mathrm{Zn}^{2+}$ ions

\section{Discussion}

The transmembrane potential plays a key role in development of organism, regeneration and disease. But in the literature, there is little information on the transmembrane potential and the effects of heavy metals on the dynamic of this bioelectric signal in early stages of embryo development.

Previous study has reported the degree of similarity between the transmembrane potentials of loach Misgurnus fossilis L. embryo cells at the early stages of embryo development interacting with heavy metals in the incubation media (Boiko \& Sanagursky, 2000; Ivashkiv et al., 2001).

Correlation strength between pairs of the transmembrane potentials differs with the time shift. This relationship is illustrated in (Fig 1). It is shown that the correlation strength decreases as the lag increases increase up to $180 \mathrm{~min}$. It can be assumed that the decrease in the correlation strength with the time shifts is due to the fact that $\mathrm{Ni}^{2+}, \mathrm{Co}^{2+}, \mathrm{Sn}^{2+}$ ions have an inhibitory effect on active transport systems, that maintain the transmembrane potential of the cell. Boiko et al. (2004) have reported changes in the $\mathrm{Na}^{+}, \mathrm{K}^{+}$-ATPase activity under influence of the heavy metals (Chen et al., 2017). The enzymatic sensitivity to heavy metals is different in early embryo development and the $\mathrm{Na}^{+}, \mathrm{K}^{+}$-ATPase exhibits the greatest inhibition activity against $\mathrm{Ni}^{2+}$ ions (Boiko et al., 2004). The closeness of the relationship between transmembrane potential for embryos incubated in media with $\mathrm{Zn}^{2+}$ and in the control solution remains moderate or weak with increasing time shifts. Obviously, this result is due to the fact that $\mathrm{Zn}^{2+}$, as an important trace element in the life cycle of embryonic organisms (Vallee \& Falchuk, 1993; Dehbandi et al., 2020), antagonizes the toxic effects of heavy metals (Formigari et al., 2007). Since Zn is a metal that competes with $\mathrm{Ca}$ in the gill surface and can inhibit the $\mathrm{Ca}^{2+}$-channels (Cousins et al., 2006) and $\mathrm{Ca}^{2+}$ influx and $\mathrm{K}^{+}$or $\mathrm{Na}^{+}$efflux through specific ionic channels change the transmembrane potential of the embryo cell this results in indirect influence of this trace metal on the membrane potential. The more the weight of the correlation graph falls, the more the effect of the environmental factor, as heavy metals in the incubation solution, on the embryo development is effective.

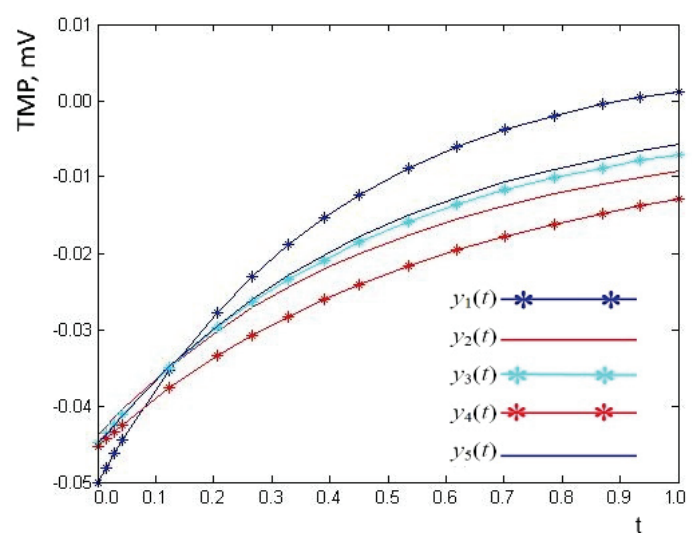

Fig. 8. The dynamics of transmembrane potential at time shift $\tau=$ $180 \mathrm{~min}$ : (1) the rate of change of the transmembrane potential of an embryo cell incubated in Golfreter's solution, (2) the rate of change of the transmembrane potential of an embryo cell incubated in a medium with $\mathrm{Ni}^{2+}$ ions, (3) the rate of change of the transmembrane potential of an embryo cell incubated in a medium with $\mathrm{Co}^{2+}$ ions, (4) the rate of change of the transmembrane potential of an embryo cell incubated in a medium with $\mathrm{Sn}^{2+}$ ions, (5) the rate of change of the transmembrane potential of an embryo cell incubated in a medium with $\mathrm{Zn}^{2+}$ ions

The graph structures proposed in the work were used to visualize a qualitative change in the regulation of the magnitude of the transmembrane potential by heavy metals. In order to better understand the effect of heavy metals on the transmembrane potential the mathematical model was constructed with sum cross-correlation coefficients. A mathematical model describing the dynamics of transmembrane potential in embryonic objects at the stage of early embryonic development is developed. They also serve to phenomenologically describe the processes represented by a set of elements with known characteristics. Using this approach, it is shown that the simultaneous action of the ions group cause changes in the transmembrane potential, which are fixed in the time shift before the second division. And the critical moment of change of the transmembrane potential is found from time shift of $90 \mathrm{~min}$. The results obtained by numerical solution of systems of equations indicate a consistent change in the coefficient $\mathrm{km}$ between the transmembrane potential of embryo cells incubated in five solutions. The nature of the change $\mathrm{km}$ between the pair elements of the system indicates the degree of their belonging to the processes of generation of the transmembrane potential of the embryonic cell. The general decline $\mathrm{km}$ indicates the growing role of higher order subsystems, which are components of the plasma membrane, in embryogenesis.

There are oscillatory changes in the membrane properties of cleaving embryos from the value of approximately $-40 \mathrm{mV}$ at the first division to approximately $-70 \mathrm{mV}$ after the fifth division (Bregestovski, 1992). The transmembrane potential with lag and effects of heavy metals change the magnitude to positive value. That can be explained by long term effect of heavy metals on transport systems of embryo cells that maintain the transmembrane potential. 
The dynamics of the transmembrane potential were determined by equal behaviour at the time shift $0 \mathrm{~min}$, and $30 \mathrm{~min}$ that can be explained by strong correlation dependence. Thus, as the total strength of the relationship between the two curves describing the dynamic of the transmembrane potential of the embryo cell decreases under the action of factors, the functions describe the following properties: (1) the function is monotonic and convex, (2) the function is monotonic and changes the direction of convexity. The function acquires positive values at time shifts from $\tau=$ $90 \mathrm{~min}$ up to $\tau=180 \mathrm{~min}$. These simulations also show that the values of cross-correlation coefficients (Razzhevaikin \& Shpitonkov, 2008) directly affect the behaviour of functions.

The processes that cause general changes in the level of transmembrane potential in the studied time interval are closely related. Characters of changes in the total strength of correlations between pairs of elements in the system $\mathrm{y}_{1}(\mathrm{t}), \mathrm{y}_{2}(\mathrm{t}), \ldots, \mathrm{y}_{5}(\mathrm{t})$ are illustrated with diagrams (Fig. 1). Direction of decreasing value $\mathrm{km}$ observed with increasing magnitude of the time shift. The coefficient $\mathrm{km}$, considered between the pair elements of the system, gradually changes the maximum value with time shifts from one of the studied pairs to others. Obviously, this determines the change in the generation of transmembrane potential. Thus, the curves of the transmembrane potential of the embryo cells are characterized by transient behaviour, which is determined by the chemical composition of the incubation medium for cold-blooded animals and the effects caused by time shifts. Heavy metals directly affect the systems of the plasma membrane that maintain the membrane potential, and their sensitivity to ions changes over time. From the heavy metals used in the various concentrations, zinc was proved to be the most toxic heavy metal causing increased risk of mortality and shorter life expectancy for zebrafish eggs (Gouva et al., 2020). In the diagrams, this assumption is represented by small values the correlations at large time shifts. Graphically, this assumption can be explained by the approximation of the value of the membrane potential to zero values.

\section{Conclusion}

Therefore, we used the results of studies of the transmembrane potential of cells incubated in media with heavy metals of known concentration. The structures of pairwise interdependencies between the indicators of the transmembrane potential for given time shifts are constructed. The mathematical model qualitatively reproduces the structure of functional interactions of individual elements of the system. In conclusion, this study is one of the attempts to model change of influence of heavy metals that have been experimentally observed in the different animal objects. Theoretical evidence yielded by this study supports that the leadership effect of heavy metals on the transmembrane potential of embryo cells in early embryo development changes with time shifts. The combined effects of various metal mixtures are complicated and need to be further studied in diverse marine species.

\section{References}

Abdul Kadir, L., Stacey, M., \& Barrett-Jolley, R. (2018). Emerging roles of the membrane potential: Action beyond the action potential. Frontiers in Physiology, 9,1661 .

Aldavood, S. J., Abbott, L. C., Evans, Z. R., Griffin, D. J., Lee, M. D., Quintero-Arevalo, N. M., \& Villalobos, A. R. (2020). Effect of cadmium and nickel exposure on early development in zebrafish (Danio rerio) embryos. Water, 12(11), 3005.

Anderson, J. A. (2001). Discrete mathematics with combinatorics. Prentice Hall, New Jersey.

Bhagat, J., Zang, L., Nishimura, N., \& Shimada, Y. (2020). Zebrafish: An emerging model to study microplastic and nanoplastic toxicity. Science of the Total Environment, 2020, 138707.

Boiko, N., \& Sanagursky, D. (2000). Dynamika transmembrannoho potentsialu zarodkiv v'yuna v umovakh vplyvu ioniv vazhkykh metaliv [Dynamics of transmembrane potential of germ breeding in conditions of influence of heavy metal ions] Visnyk L'vivs'koho Universytetu, Seriya Biolohichna, 25, 3-7 (in Ukrainian).

Boiko, N. M., Tselevych, M. V., \& Sanagursky, D. I. (2004). Aktyvnist' $\mathrm{Na}^{+}, \mathrm{K}^{+}$ ATFazy membran zarodkiv v'yuna (Misgurnus fossilis L.) za diyi kationiv vazhkykh metaliv [Activity of membrane $\mathrm{Na}^{+}, \mathrm{K}^{+}$-ATP-ase of embryos of loach (Misgurnus fossilis L.) under the influence of heavy metal cations]. Ukrayinskyy Biokhimichnyy Zhumal, 76(2), 59-63 (in Ukrainian).
Bregestovski, P., Medina, I., \& Goyda, E. (1992). Regulation of potassium conductance in the cellular membrane at early embryogenesis. Journal of PhysiologyParis, 86, 109-115.

Cervera, J., Manzanares, J. A., Mafe, S., \& Levin, M. (2019). Synchronization of bioelectric oscillations in networks of nonexcitable cells: From single-cell to multicellular states. The Journal of Physical Chemistry B, 123(18), 3924-3934.

Cervera, J., Pietak, A., Levin, M., \& Mafe, S. (2018). Bioelectrical coupling in multicellular domains regulated by gap junctions: A conceptual approach. Bioelectrochemistry, 123, 45-61.

Chen, C., Bu, W., Ding, H., Li, Q., Wang, D., Bi, H., \& Guo, D. (2017). Cytotoxic effect of zinc oxide nanoparticles on murine photoreceptor cells via potassium channel block and $\mathrm{Na}^{+} / \mathrm{K}^{+}$-ATPase inhibition. Cell Proliferation, 50(3), e12339.

Chrishtop, V. V., \& Pakhrova, O. A. (2014). Primeneniye klasternogo i korrelyatsionnogo analiza dlya otsenki gemoreologicheskikh pokazateley u bol'nykh essentsial'noy arterial'noy gipertenziyey [Application of cluster and correlation analysis to assess hemorheological parameters in patients with essential arterial hypertension]. Uspekhi Sovremennogo Yestestvoznaniya, 9, 11-16 (in Russian).

Cousins, R. J., Liuzzi, J. P., \& Lichten, L. A. (2006). Mammalian zinc transport, trafficking, and signals. Journal of Biological Chemistry, 281(34), 24085-24089.

Curis, E., Nicolis, I., Bensaci, J., Deschamps, P., \& Bénazeth, S. (2009). Mathematical modeling in metal metabolism: Overview and perspectives. Biochimie, 91(10), 1238-1254

Dehbandi, R., Fakhri, Y., Sarafraz, M., Nematolahi, A., Dehghani, S. S., Gholizadeh, A., \& Khaneghah, A. M. (2020). Potentially toxic elements (PTEs) in the fillet of narrow-barred spanish mackerel (Scomberomorus commerson): A global systematic review, meta-analysis and risk assessment. Biological Trace Element Research, 2020, 1-10.

Dos Santos, J. A., Soares, C. M., \& Bialetzki, A. (2020). Effects of pH on the incubation and early development of fish species with different reproductive strategies. Aquatic Toxicology, 219, 105382.

Gárriz, Á., \& Miranda, L. A. (2020). Effects of metals on sperm quality, fertilization and hatching rates, and embryo and larval survival of pejerrey fish (Odontesthes bonariensis). Ecotoxicology, 29(7), 1072-1082.

Gerasimenko, T. N., Senyavina, N. V., Anisimov, N. U., \& Tonevitskaya, S. A. (2016). A model of cadmium uptake and transport in Caco-2 cells. Bulletin of Experimental Biology and Medicine, 161(1), 187-192.

Gökalp, F. D., Doğanlar, O., Doğanlar, Z. B., \& Güner, U. (2020). The genotoxic effects of mixture of aluminum, arsenic, cadmium, cobalt, and chromium on the gill tissue of adult zebrafish (Danio rerio Hamilton, 1822). Drug and Chemical Toxicology, 2020, 1-10.

Gouva, E., Nathanailides, C., Skoufos, I., Paschos, I., Athanassopoulou, F., \& Pappas, I. S. (2020). Comparative study of the effects of heavy metals on embryonic development of zebrafish. Aquaculture Research, 51(8), 3255-3267.

Grech, A., Brochot, C., Dorne, J. L., Quignot, N., Bois, F. Y., \& Beaudouin, R. (2017). Toxicokinetic models and related tools in environmental risk assessment of chemicals. Science of the Total Environment, 578, 1-15.

Isaza, D. F. G., Cramp, R. L., \& Franklin, C. E. (2020). Living in polluted waters: A meta-analysis of the effects of nitrate and interactions with other environmental stressors on freshwater taxa. Environmental Pollution, 261, 114091.

Ivashkiv, L., Hraduk, M., \& Sanagursky, D. (2001). Analiz kros-korelyatsiy u chasovykh zminakh fizyko-khimichnykh pokaznykiv rozvytku zarodkiv v'yuna [Analysis of cross-correlations in temporary changes of physical and chemical parameters of loach germs' development]. Visnyk L'vivs'koho Universytetu, Seriya Biolohichna, 27, 3-11 (in Ukrainian).

Jakimska, A., Konieczka, P., Skóra, K., \& Namieśnik, J. (2011). Bioaccumulation of metals in tissues of marine animals, Part I: The role and impact of heavy metals on organisms. Polish Journal of Environmental Studies, 20(5), 1117-1125.

Kennedy, C. J. (2011). Toxicology: The toxicology of metals in fishes. In: Encyclopedia of fish physiology. Elsevier, New York. Pp. 2061-2068.

Kerekes, F., Kollár, T., Gazsi, G., Kása, E., Urbányi, B., Csenki-Bakos, Z., \& Horváth, Á. (2020). Investigation of fertilizing capacity of zebrafish (Danio rerio) sperm exposed to heavy metals. Dose-Response, 18(2), 1559325820919597.

Klein, R. D., Nogueira, L. S., Domingos-Moreira, F. X. V., Costa, P. G., Bianchini, A., \& Wood, C. M. (2019). Effects of sublethal Cd, Zn, and mixture exposures on antioxidant defense and oxidative stress parameters in early life stages of the purple sea urchin Strongylocentrotus purpuratus. Aquatic Toxicology, 217, 105338.

Lacave, J. M., Retuerto, A., Vicario-Parés, U., Gilliland, D., Oron, M., Cajaraville, M. P., \& Orbea, A. (2016). Effects of metal-bearing nanoparticles (Ag, Au, $\mathrm{CdS}, \mathrm{ZnO}, \mathrm{SiO}_{2}$ ) on developing zebrafish embryos. Nanotechnology, 27(32), 325102

Levin, M., \& Martyniuk, C. J. (2018). The bioelectric code: An ancient computational medium for dynamic control of growth and form. Biosystems, 164, 76-93.

Martinez, C. S., Igartúa, D. E., Calienni, M. N., Feas, D. A., Siri, M., Montanari, J., Chiaramoni, N. S., Alonso, S. del D., \& Prieto, M. J. (2017). Relation between biophysical properties of nanostructures and their toxicity on zebrafish. Biophysical Reviews, 9(5), 775-791. 
Pai, V. P., Martyniuk, C. J., Echeverri, K., Sundelacruz, S., Kaplan, D. L., \& Levin, M. (2016). Genome-wide analysis reveals conserved transcriptional responses downstream of resting potential change in Xenopus embryos, axolotl regeneration, and human mesenchymal cell differentiation. Regeneration, 3(1), 3-25.

Puar, P., Niyogi, S., \& Kwong, R. W. M. (2020). Regulation of metal homeostasis and zinc transporters in early-life stage zebrafish following sublethal waterborne zinc exposure. Aquatic Toxicology, 225, 105524.

Razzhevaikin, V. N., \& Shpitonkov, M. I. (2008). Korrelyatsionnaya adaptometriya. Modeli i prilozheniya $\mathrm{k}$ biomeditsinskim sistemam [Correlation adaptometry. Models and applications to biomedical systems]. Matematicheskoe Modelirovanie, 20(8), 13-27.

Seneviratne, M., Rajakaruna, N., Rizwan, M., Madawala, H. M. S. P., Ok, Y. S., \& Vithanage, M. (2019). Heavy metal-induced oxidative stress on seed germination and seedling development: A critical review. Environmental Geochemistry and Health, 41(4), 1813-1831.

Sfakianakis, D. G., Renieri, E., Kentouri, M., \& Tsatsakis, A. M. (2015). Effect of heavy metals on fish larvae deformities: A review. Environmental Research, 137, 246-255.

Sfiru, R., Cârdei, P., Vlăduţ, V., \& Matache, M. (2018). The role of mathematical modeling in research in the field of bioaccumulation of heavy metals. Annals of the Faculty of Engineering Hunedoara, 16(4), 13-18.

Shcherbachenko, O. I. (2014). Vazhki metaly yak toksychnyy faktor zabrudnennya pryrodnoho seredovyshcha. Stiykist' i adaptatsiya roslyn do yikh vplyvu [Heavy metals as a toxic factor of pollution of the natural environment. Resilience and adaptation of plants to their influence]. Naukovi Zapysky Derzhavnoho Pryrodoznavchoho Muzeyu, 59, 157-182 (in Ukrainian).

Singh, R., Gautam, N., Mishra, A., \& Gupta, R. (2011). Heavy metals and living systems: An overview. Indian Journal of Pharmacology, 43(3), 246.

Sonnack, L., Klawonn, T., Kriehuber, R., Hollert, H., Schäfers, C., \& Fenske, M. (2017). Concentration dependent transcriptome responses of zebrafish embryos after exposure to cadmium, cobalt and copper. Comparative Biochemistry and Physiology, Part D: Genomics and Proteomics, 24, $29-40$.

Sundelacruz, S., Levin, M., \& Kaplan, D. L. (2009). Role of membrane potential in the regulation of cell proliferation and differentiation. Stem Cell Reviews and Reports, 5(3), 231-246.

Tchounwou, P. B., Yedjou, C. G., Patlolla, A. K., \& Sutton, D. J. (2012). Heavy metals toxicity and the environment. In: Luch. A. (Ed.). Molecular, clinical and environmental toxicology. Springer, Basel. Pp. 133-164.

Ugwuja, E. I., Vincent, N., Ikaraoha, I. C., \& Ohayi, S. R. (2020). Zinc ameliorates lead toxicity by reducing body $\mathrm{Pb}$ burden and restoring $\mathrm{Pb}$-induced haematological and biochemical derangements. Toxicology Research and Application, 4, 2397847320956562.

Vallee, B. L., \& Falchuk, K. H. (1993). The biochemical basis of zinc physiology. Physiological Reviews, 73(1), 79-118.

Wang, W. X., \& Tan, Q. G. (2019). Applications of dynamic models in predicting the bioaccumulation, transport and toxicity of trace metals in aquatic organisms. Environmental Pollution, 252, 1561-1573.

Whited, J. L., \& Levin, M. (2019). Bioelectrical controls of morphogenesis: From ancient mechanisms of cell coordination to biomedical opportunities. Current Opinion in Genetics and Development, 57, 61-69.

Yakimenko, O. A. (2019). Engineering Computations and Modeling in MATLAB / Simulink. American Institute of Aeronautics and Astronautics, Reston.

Yoo, J. W., Cho, H., Lee, K. W., Won, E. J., \& Lee, Y. M. (2020). Combined effects of heavy metals $(\mathrm{Cd}, \mathrm{As}$, and $\mathrm{Pb})$ : Comparative study using conceptual models and the antioxidant responses in the brackish water flea. Comparative Biochemistry and Physiology Part C: Toxicology and Pharmacology, 239, 108863.

Zhou, Y., Wong, C. O., Cho, K. J., Van Der Hoeven, D., Liang, H., Thakur, D. P., \& Hu, H. (2015). Membrane potential modulates plasma membrane phospholipid dynamics and K-Ras signaling. Science, 349(6250), 873-876. 